\title{
Orpheus and the Law: The Story of Myrrha in Ovid's Metamorphoses
}

\author{
Ioannis Ziogas
}

\begin{abstract}
According to Horace, Orpheus and Amphion were the first legislators. They forbade casual sex, gave rights to spouses, and inscribed laws on wood (Ars Poetica 396-401). Orpheus, who is both the model of the devoted husband and the founding father of pederasty, simultaneously establishes and challenges the institution of marriage. His myth acquires a deeply political dimension at Rome after the emperor Augustus introduced laws that encouraged marriage and criminalised adultery. In the Metamorphoses, Orpheus attempts to regulate desire and is subsequently executed by married or marriageable women. He is a figure of Ovid, the poet who spelled out the constitution of the rules of conduct within the domains of sexual attraction in his Art of Love and was punished for subverting the institution of marriage. This article focuses on Orpheus' story of Myrrha in Ovid's Metamorphoses and reads the tale against the background of Augustus' marriage and adultery laws. The myth of Myrrha is rife with legal language and courtroom rhetoric that provocatively conflate incest with marriage.
\end{abstract}

\section{INTRODUCTION}

The tension between the irrational power of passion and the rational principles of jurisprudence has been at the centre of human society and legal theory since antiquity, from Plato's philosophy on the origins of the law to current legal debates on reforming marriage legislation. Law and love are simultaneously close relatives and polar opposites. In Plato's Symposium, ${ }^{1}$ Diotima tells Socrates that poetry and laws are the products of eros. In particular, Diotima gives the examples of the lawgivers Lycurgus and Solon, who are highly esteemed 'for fathering fine children (ie, laws)'. For Diotima, justice is the child of a man in love.

Peter Goodrich offers a wealth of theoretical insights into the relationship between law and emotion, rational judgment and the regulation of desire, and the ways in which the interior jurisdiction of spiritual and amatory law was absorbed within the common law in European history. ${ }^{2}$ From a more philosophical perspective, Bańkowski argues that law and love are entangled and even dependent on each other. ${ }^{3}$ These

1 Plato, Symposium (WRM Lamb trans, Loeb Classical Library Harvard University Press, 1975) 208-209.

2 Peter Goodrich, Law in the Courts of Love. Literature and Other Minor Jurisprudences (Routledge, 1996); Peter Goodrich, The Laws of Love: A Brief Historical and Practical Manual (Palgrave Macmillan, 2006).

3 Zenon Bańkowski, Living Lawfully: Love in Law and Law in Love (Kluwer Academic Publishers, 2001). 
critics exemplify a current trend in critical legal studies, ${ }^{4}$ which turn to other disciplines (mainly literary studies and philosophy) in an attempt to reconnect the discipline of law to questions of conscience and, more broadly, to the casuistic indeterminacies of judgment. Interdisciplinary work aspires to reopen questions of jurisdiction and the plurality of laws, interior and exterior, emotional and rational, imagined and real.

Augustan Rome is an excellent case study for the dialectic between law and love. In $18 \mathrm{BCE}$, the emperor Augustus introduced laws that encouraged marriage and criminalised adultery. Illicit sex became a criminal offence rather than a private affair and Latin love poetry flourishes under this political climate. Ovid sings of his passions (extra-marital, illicit, adulterous) and casts Cupid as an all-conquering god who trumps imperial statutes. ${ }^{5}$ The emperor intrudes into the bedrooms of Roman citizens, while poets attempt to regulate love and public affairs.

While the legislative procedures of the Roman Republic were decentralised, Augustus attempted to control the production and interpretation of law without seemingly interfering with the legal legacy of the Republic. ${ }^{6}$ The tension between poetic and imperial authority is played out against the shift from the Republic to the Principate. Augustus decisively, albeit subtly, monopolises legislation, but Augustan poets suggest the polyphony of the lawmaking procedures. The multifaceted and even mysterious sources of judicial authority ${ }^{7}$ are an endless source of anxiety for authoritative rulers who aspire to prescribe and regulate all aspects of public and private life. The more Augustus attempts to control Roman society through legislation and the performance of justice, the more it becomes obvious that poetic genres such as satire, epic, and love elegy claim a great part of the elusive source of judicial authority. The professionalisation of legal experts under Augustus clashes with the poetic justice of learned poets. ${ }^{8}$

Legal and poetic discourses offer different normative and analytic responses to natural demands and their social constructions, and these different responses relate to one another in the social sphere. It is sometimes argued that while judicial opinions have authority because they persuade and command, literature lacks law's power to marshal force. ${ }^{9}$ Yet

4 See, for example, Austin Sarat, Matthew Anderson and Cathrine O Frank, Law and the Humanities: An Introduction (Cambridge University Press, 2009).

$5 \quad$ Study of legalisms in Ovid starts with Edward Kenney, 'Ovid and the Law' (1969) 21 Yale Classical Studies 241.

6 Luigi Capogrossi Colognesi, Law and Power in the Making of the Roman Commonwealth (Cambridge University Press, 2014) 320-337.

7 See Jacques Derrida, 'Force of Law: The "Mystical Foundation of Authority" (Mary Quaintance trans) (1989-1990) 11 Cardozo Law Review 920.

8 On Ovid's poetry as a response to current judicial developments under Augustus, see Kathryn Balsley, 'Between two Lives: Teiresias and the Law in Ovid's Metamorphoses' (2010) 7 Dictynna 15; and 'Truthseeking and Truthmaking in Ovid's Metamorphoses I.163-245' (2011) 23 Law and Literature 48.

9 See Sanford Levinson, 'The Rhetoric of the Judicial Opinion' in Peter Brooks and Paul Gewirtz (eds), Law's Stories: Narrative and Rhetoric in Law (Yale University Press, 1996) 187-205. 
Siegel has rightly questioned the dichotomy between force and persuasion, arguing that power and knowledge are mutually constitutive. ${ }^{10}$ The power of law to move from the conceptual (persuasion) to the physical (violence) is also a major preoccupation of Latin love poetry. Physical attraction and persuasive seduction have the power to institute and enforce the laws of desire. Lovemaking appears as a trope of lawmaking.

\section{ORpheus And MarRiage Legislation}

The myth of Orpheus, the legendary bard who could set the elements of nature in motion with his song, is inextricably linked to his doomed marriage. Orpheus loses his beloved wife Eurydice twice; first, when she dies shortly after their wedding, and second, when he goes down to the Underworld, convinces the lord of the dead to restore Eurydice to life, but fails to heed the condition according to which he had to refrain from looking back at her before reaching the upper world. After failing to revive Eurydice, Orpheus rejects women altogether and channels his desire to homoerotic affairs. According to the mythological tradition followed by Ovid, the bard starts as the model of the devoted husband and ends as a founding father of pederasty. The married women of Thrace, offended by Orpheus' abstinence from heterosexual intercourse, punish him by tearing his body to shreds. ${ }^{11}$

As a myth that revolves around the idealisation and renunciation of marriage, the story of Orpheus acquires a deeply political dimension in Augustan Rome. ${ }^{12}$ This paper aims to analyse the politics of Ovid's version of Orpheus ${ }^{13}$ and examine the tension between Ovid's narrative and Augustus' marriage laws. ${ }^{14}$ In my view, the myth of Orpheus in Augustan poetry encourages reflection on imperial legislation. Horace, a poet who shares with Ovid an interest in the legal authority of Orpheus, argues that affection and poetry are the foundations of civilisation and marriage legislation. In his Ars Poetica, he claims that legendary bards (Orpheus

10 Reva Siegel, 'In the Eyes of the Law: Reflections on the Authority of Legal Discourse' in Peter Brooks and Paul Gewirtz (eds) Law's Stories: Narrative and Rhetoric in Law (Yale University Press, 1996) 225-231.

11 Metamorphoses 11.3. For a translation of the Metamorphoses, see Allen Mandelbaum, The Metamorphoses of Ovid (Harcourt Brac, 1995), while for the Latin text, see Richard J Tarrant, Ovidi Nasonis Metamorphoses (Oxford University Press, 2004). All translations of Ovid quoted in this article are my own.

12 On Ovid's Orpheus and Augustan ideology, see, eg, Charles Segal, Orpheus: The Myth of the Poet (Johns Hopkins University Press, 1989) 54-72.

13 Metamorphoses 10-11.

14 On Augustus' legislation that encouraged marriage and criminalised adultery, see Leo Ferrero Raditsa, 'Augustus' Legislation Concerning Marriage, Procreation, Love Affairs and Adultery' (1980) 2(13) Aufstieg und Niedergang der römischen Welt 278; Susan Treggiari, Roman Marriage: Iusti Coniuges from the Time of Cicero to the Time of Ulpian (Oxford University Press, 1991) 277-298 and 454-457; and Thomas AJ McGinn, Prostitution, Sexuality and the Law in Ancient Rome (Oxford University Press, 1998) 70-245. 
and Amphion) are the founding fathers of human society; they stopped primitive men from killing each other, founded cities, forbade promiscuity, established marriage legislation, and set up legal inscriptions:

Silvestris homines sacer interpresque deorum
caedibus et victu foedo deterruit Orpheus,
dictus ob hoc lenire tigris rabidosque leones.
dictus et Amphion, Thebanae conditor urbis
saxa movere sono testudinis et prece blanda
ducere quo vellet. fuit haec sapientia quondam,
publica privatis secernere, sacra profanis,
concubitu prohibere vago, dare iura maritis,
oppida moliri, leges incidere ligno.
sic honor et nomen divinis vatibus atque
carminibus venit. ${ }^{15}$

While men still roamed the woods, Orpheus, the holy prophet of the gods, made them shrink from bloodshed and brutal living; hence the fable that he tamed tigers and ravening lions; hence too the fable that Amphion, builder of Thebes' citadel, moved stones by the sound of his lyre, and led them whither he would by his supplicating spell. Once this was wisdom, to discern public from private affairs, sacred from profane, to check casual sex, to give rights to spouses, to build cities, to inscribe laws on wood. So honour and renown fell to divine bards and their songs. ${ }^{16}$

For Horace, marriage legislation lays the foundation of human society. The laws that control sexual intercourse are not simply an aspect of the legal system, but lie at the heart of human civilisation. The first step is to separate public from private rights,,${ }^{17}$ the second the sacred from the profane, and then the wisdom of the bards managed to regulate sex and institute marriage. The foundation of cities and the inscription of laws become possible only after those first steps. Thus, the rules that regulate human intercourse precede State laws. Law is born out of the necessity to curb unrestrained libido and out of the desire to bring people together harmoniously. Turning desire into the cornerstone of a harmonious society is the very basis of the legal system. ${ }^{18}$ The so-called laws of the first Venus are the foundations of justice. ${ }^{19}$

15 Horace, Ars Poetica 391-401. The Latin text is from Niall Rudd, Horace: Epistles Book II and Ars Poetica (Cambridge University Press, 1990).

16 Translation with occasional modifications from Horace, Satires, Epistles, The Art of Poetry (H Rushton Fairclough trans, Loeb Classical Library, 1926) 482-483.

17 By contrast, Augustus' socio-legal statutes blend public with private matters by criminalising private affairs. For the first time, illicit affairs were punished by trial in a standing criminal court, the quaestio perpetua de adulteriis; see McGinn, above n 14, 141; Raditsa, above n 14, 329-334. On Ovid's response to this issue, see Balsley, above $\mathrm{n} 8$.

18 On the unity of law and love, see Michael J Detmold, The Unity of Law and Morality. A Refutation of Legal Positivism (Lawbook Co of Australasia, 1984); Bańkowski, above n 3; Goodrich, above n 2.

19 For Eros as law and the laws of the first Venus, see Goodrich, above n 2. For Goodrich, the 'laws of first Venus', the laws of nature, are opposed to the prudential rules of the 'second Venus', that is positive law. 
Just as the laws of love precede and are a sine qua non of State laws, poetic diction is the very origin of legal authority. The divine poets of the past, Orpheus and Amphion, had the power to tame wild beasts, build city walls, and charm rocks with their 'flattering spell' (prece blanda). Their songs are described in terms that belong to the discourse of seduction in Latin love poetry, ${ }^{20}$ in which the lover commonly tries to move the beloved with flattering words. The poetic force that built cities and made people organise themselves in civilised societies relies on the poetics of love poetry. A song that has the power to move (movere) even rocks lies at the heart of Latin love elegy, a genre that employs poetry in order to charm and move a mistress who is often presented as hard and harsh as a rock. A moving song that has the power to change human relations is a song with legal power. The key word carmen ('charm', 'incantation', 'song', 'poem') describes powerful verse that can bring about a physical reaction that reifies the speaker's wishes; it can refer to legal, amatory, and magical diction, three examples of potent language with illocutionary force. ${ }^{21}$ Thus, Horace associates Orphic poetry with the introduction of legislation and the origins of human civilisation with amatory justice.

The Augustan poets (Vergil, Horace, Tibullus, Propertius, Ovid) establish carmen as a word referring to their works, thus making a statement about the power of their poetry to make a difference in the world of Roman society and the laws that control it. ${ }^{22}$ Poetic discourse does not reflect or comment on Roman legislation but aspires to take part in lawmaking.

\section{ORPheus as AUCTOR}

The appearance of Orpheus as a legislator of marriage laws in Horace is intriguing if we consider that Ovid gives us an extensive narrative of Orpheus' performance after the bard renounced intercourse with women and introduced the custom of pederasty in Thrace. Orpheus' new sexual orientation is cast as a legislative act:

Ille etiam Thracum populis fuit auctor amorem

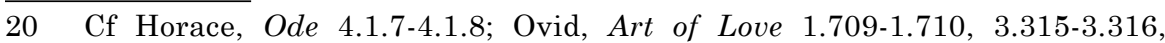
Metamorphoses 10.642. For text and translation of Horace's Odes, see Horace, Odes and Epodes (Niall Rudd edition and trans, Loeb Classical Library, 2004). For text and translation of Ovid's Art of Love, see Ovid, Art of Love. Cosmetics. Remedies for Love. Ibis. Walnut-tree. Sea Fishing. Consolation (JH Mozley trans, revised by GP Goold, Loeb Classical Library, 1929).

21 See Michael CJ Putnam, Horace's 'Carmen Saeculare': Ritual Magic and the Poet's Art (Yale University Press, 2000) 132; Thomas Habinek, The World of Roman Song (Johns Hopkins University Press, 2005); Michèle Lowrie, Writing, Performance, and Authority in Augustan Rome (Oxford University Press, 2009) 327 and passim.

22 Ovid claims that his exile was because of carmen et error. The potential legal overtones of carmen are further suggested by the legal arguments that Ovid employs in his exile poetry in order to imply the injustice that arises when we compare the mildness of his offence with the severity of his punishment. On this topic, see Matthew McGowan, Ovid in Exile: Power and Poetic Redress in the Tristia and Epistulae ex Ponto (Brill, 2009) 41-55; Lowrie, above n 21, 360-382. 
in teneros transferre mares.

he was the first in the people of Thrace to transfer love to tender boys. ${ }^{23}$

The word auctor, which can mean an ancestor or father, may imply the model of pederasty as a father-son relationship, but in combination with transferre, the diction further implies a legal transaction or transference of rights or property. ${ }^{24}$ Orpheus is an auctor in the sense that he is an authoritative guarantor who gives his approval in transferring the right of amatory passion to tender boys. These meanings of auctor and transferre are commonly found in the texts of the jurists. ${ }^{25}$ In a legal context, transferre also means to apply a legal principle to an analogous case. ${ }^{26}$ In Orpheus' case, the bard transfers the rules that govern heterosexual desire to homoerotic affairs.

As a legislator of homoerotic affairs, Orpheus is an auctor legis, meaning that he is the proposer or ratifier of a statute that governs extramarital love. From that perspective, his legislative agenda overlaps with that of Augustus.

Legibus novi[s] $\mathrm{m}[\mathrm{e}$ auctore l]atis $\mathrm{m}[\mathrm{ulta}$ e]xempla maiorum exolescentia iam ex nostro [saecul]o red[uxi et ipse] multarum rer[um exe]mpla imitanda pos[teris tradidi.]

By new laws passed on my initiative I brought back into use many exemplary practices of our ancestors which were disappearing in our time, and in many ways I myself handed down to later generations many exemplary practices for them to imitate. ${ }^{27}$

Augustus used his tribunicia potestas to submit legislation to the people and his influence to have his laws passed. Scholars agree that Augustus here refers to his marriage legislation. ${ }^{28}$ Orpheus and Augustus are both auctores of laws that govern human morals and desire, and they both legislate by means of influence and exemplarity. But while one of the aims of Augustus' laws was the production of legitimate children, Orpheus' new laws of homosexual love rule out the possibility of biological children and thus go against the grain of imperial legislation.

A passage in the Metamorphoses actually resembles Augustus' Res Gestae:

Pace data terris animum ad civilia vertet

iura suum legesque feret iustissimus auctor

23 Metamorphoses 10.83-10.84. Translated from Tarrant, above $\mathrm{n} 11$.

24 See Ulrich Gebhardt, Sermo Iuris: Rechtssprache und Recht in der augusteischen Dichtung (Brill, 2009) 111; 328-329; cf Metamorphoses 15.34-15.35.

25 See Digest 4.7.3.4; 9.4.27.1; cf Cicero, De officiis 1.43. For text and translation of the Digest, see The Digest of Justinian (Latin text edited by Theodor Mommsen and Paul Krueger; trans Alan Watson, University of Pennsylvania Press, 1985). For text and translation of Cicero, see Cicero, On Duties (Walter Miller trans, Loeb Classical Library, 1913).

26 See Adolf Berger, Encyclopedic Dictionary of Roman Law (American Philosophical Society, first published 1953, 1991 ed) 740.

27 Augustus, Res Gestae 8.5. Translated from Alison Cooley, Res Gestae Diui Augusti: Text, Translation, and Commentary (Cambridge, 2009).

28 See Cooley, above n 27, 143; Lowrie, above n 21, 301-303, 360-361. 
exemploque suo mores reget inque futuri temporis aetatem venturorumque nepotum prospiciens prolem sancta de coniuge natam ferre simul nomenque suum curasque iubebit.

When peace has been given to the lands, he will turn his attention to civil legislation and as a most just author carry laws and he will rule morals by his own example and looking to the age of future time and of grandchildren to come, he will order the offspring born of his holy wife to bear at the same time his own name and cares. ${ }^{29}$

Ovid describes the emperor as the iustissimus auctor of a moral legislation. Augustus first establishes universal peace and then turns his attention to marriage legislation. This progression resembles the origins of human civilisation and legislation as, for instance, Horace shows in Satire 1.3.99ff. The laws that regulate desire guarantee the peaceful co-existence of human societies. Ovid's praise of imperial laws is followed by a passage about the emperor's grandchildren and his adoption of Tiberius, but the combination of Augustus' laws and offspring feels a bit uncomfortable. No amount of moral legislation could produce Augustus a biological heir or chaste daughters and granddaughters. ${ }^{30}$ Augustus' role as an auctor, a proposer of legal reforms, is problematised by his role as a father or progenitor, the other meaning of auctor.

\section{ORPheus AND Ovid}

Ovid's Orpheus challenges the institution of marriage and establishes a doctrine of extra-marital desire. From that perspective, he is a 'teacher of love' (praeceptor amoris), ${ }^{31}$ Ovid's alter ego, and is eventually punished for his poetic wanderings into forbidden territory, not unlike Ovid, who was exiled partly, it is thought, because his subversive Art of Love could have been read as an encouragement to illicit liaisons. Recent scholarship on Ovid examined the similarities between the recurring motif of art and punishment in the Metamorphoses and the fate of Ovid himself. ${ }^{32}$ In these studies, Orpheus features prominently as a figure of Ovid and I would like to examine some of the aspects of Orpheus' narrative that resonate with Augustan legislation and make this mythological figure relevant to the realities of Ovid's Rome. A passage from the Metamorphoses that clearly echoes Ovid's persona of the teacher of love is Orpheus' ritual cry that warns daughters and parents about the X-rated contents of the story he is about to tell. Members of decent families should keep a distance from the tale of Myrrha, the daughter who fell madly in love with her father:

$29 \quad$ Metamorphoses 15.832-15.838. Translated from Tarrant, above n 11.

30 Lowrie, above n 21, 379-380.

31 Ovid's Art of Love is a didactic poem in which Ovid assumes the persona of 'the teacher of love.'

32 Patricia Johnson, Ovid before Exile: Art and Punishment in the Metamorphoses (University of Wisconsin Press, 2008); Barbara Pavlock, The Image of the Poet in Ovid's Metamorphoses (University of Wisconsin Press, 2009). 
Dira canam; procul hinc natae, procul este parentes aut, mea si vestras mulcebunt carmina mentes, desit in hac mihi parte fides, nec credite factum, vel, si credetis, facti quoque credite poenam.

I shall sing a dreadful song; stay away, daughters, stay away, parents, or, if my songs are pleasing your minds, do not trust me in this part, don't believe that it happened, or, if you believe, also believe the punishment for the deed..$^{33}$

The passage employs the ritual cry ('stay away!') that excludes the uninitiated and ritually unclean. The formula befits Orpheus, a mythic figure closely associated with mystery cults and their rituals of initiation. ${ }^{34}$ While employing the ritual cry of the Orphic mysteries, Ovid playfully suggests that the pure daughters and parents rather than the ritually unclean (profani) must be excluded from his audience. ${ }^{35}$ Horace attributed the separation of the sacred from the profane to the old bards, but the ritual initiation of Ovid's Orpheus suggests a perverse cult that is suitable to the profane.

Orpheus next introduces the issue of the myth's truthfulness as part of his disclaimer. Should you listen to my story, he says, do not believe it. This is ironic since the initiates were supposed to be enlightened with the truth, not with false tales. Then, by adding that if one believes the story, they should also believe the punishment, he immediately undermines what he said first. Ovid's Orpheus asks us to believe the implausible fantasy (that is, Myrrha's transformation) and dismiss the believable (that is, that a daughter can be sexually attracted to her father). As Barchiesi puts it, the transgression is realistic, the expiation pure fantasy. ${ }^{36}$ As he recants his suggestions one after another, Orpheus undermines the validity of his warning. His disingenuous invitation to disbelief is an inversion of the typical statement to tell the truth and only the truth in court. The audience should give trust to his tale (fides, credite) only if they also believe in the punishment for the deed. The bard promises a narrative of crime and punishment, and his disclaimer prepares his audience for a tale rife with courtroom rhetoric. ${ }^{37}$

33 Metamorphoses 10.300-10.303. Translated from Tarrant, above n 11.

34 See Joseph Reed, Metamorfosi 10-12 (Mondadori, 2013) 234.

35 See William S Anderson, Ovid, Metamorphoses 6-10 (University of Oklahoma Press, 1972); Gareth Williams, Banished Voices: Readings in Ovid's Exile Poetry (Cambridge University Press, 1994) 206-207.

36 See Alessandro Barchiesi, Speaking Volumes: Narrative and Intertext in Ovid and Other Latin Poets (Duckworth Academic, 2001) 59. Orpheus theorises on the right way of interpreting poetic myths and touches upon the issue of believing in myths and their moral values. The question of believing in Ovid's magically realistic world is a main preoccupation of the Metamorphoses. See, for example, Denis C Feeney, The Gods in Epic: Poets and Critics of the Classical Tradition (Clarendon Press, 1991) 188-249.

37 Kathryn Balsley, The Performance of Justice in Imperial Latin Literature (Dissertation, Stanford University, 2001) examines the ways in which Latin authors (Livy, Ovid, Seneca) cast the trial scene topos as the authors' re-performance at the level of narrative. See also Gebhardt, above $n$ 24, 283-303 on how Ovid presents his search for true aitia in the Fasti as a trial. 
Behind the clever paradoxes of Orpheus' song lies the witty persona of Ovid, the love poet. Orpheus echoes Ovid's initial disclaimer in his Art of Love:

Vera canam: coeptis, mater Amoris, ades!

Este procul, vittae tenues, insigne pudoris,

Quaeque tegis medios, instita longa, pedes.

Nos Venerem tutam concessaque furta canemus,

Inque meo nullum carmine crimen erit.

I shall sing a truthful song: support my undertaking, mother of Amor! Stay away, slender fillets, symbol of modesty, and you, long hem, who cover half the feet: we shall sing of safe Venus and permitted cheating and there will be no wrong in my song. ${ }^{38}$

Orpheus' dira canam echoes Ovid's vera canam. In contrast with Orpheus, Ovid proclaims that he sings of true things. The programmatic disclaimer of the Art of Love suggests a testimony given in court. 'I shall tell the truth' resembles a witness' statement and further evokes a legal dispute by alluding to Hesiod's 'I shall tell Perses the truth', ${ }^{39}$ a declaration given in the context of Hesiod's invocation of Zeus to 'straighten verdicts with justice'. ${ }^{40}$ Ovid asks Venus to appear as an advocate for his work, a meaning of ades which may be in play here ${ }^{41}$ He further evokes the setting of a courtroom with the legally fraught concessaque furta ('permissible thefts'), which echoes and contrasts with the legal language of Orpheus, who sings of forbidden passions that deserve punishment (canamus ... / inconcessisque puellas / ignibus attonitas meruisse libidine poenam, 'let us sing ... of girls stricken by forbidden fires, who deserved punishment for their lust'). ${ }^{42}$ The exculpation of his carmen from crimen leaves no doubt about the legal dimension of the poet's statement. Of course, both Ovid's and Orpheus' declarations are subversive and disingenuous. Concessa furta ('legitimately illegitimate affairs') is oxymoronic and the word order of carmine crimen invites the reader to see that all the letters of carmen fit into crimen. Orpheus wards off daughters and parents, while Ovid gets rid of their clothes and we can read this passage as the praeceptor's removing of clothes that symbolise female chastity. ${ }^{43}$ Neither Ovid nor

38 Art of Love 1.30-1.34. Translated from EJ Kenney, P Ovidi Nasonis, Amores, Medicamina Faciei Femineae, Ars Amatoria, Remedia Amoris (Oxford University Press, 1994).

39 Works and Days 10. For text and translation of the Works and Days, see Hesiod, Theogony. Works and Days. Testimonia (Glenn W. Most edition and trans, Loeb Classical Library, 2007).

40 Works and Days 9. In the Works and Days, Hesiod attempts to settle his dispute with his brother Perses out of court. As a didactic poem, it is an important intertext for the Art of Love. On the issue of truth in Ovid's literary trial of Lycaon, see Balsley, above n 8, 48-70.

41 Cf Ovid, Remedia 663; see Oxford Latin Dictionary, adsum 12.

42 Metamorphoses 10.152-10.154.

43 Ioannis Ziogas, 'Stripping the Roman Ladies: Ovid's Rites and Readers' (2014) 64(2) Classical Quarterly 735 argues that in his disclaimer Ovid removes the symbols of respectable women, namely their clothing, not necessarily the women themselves. Thus, the praeceptor is rendering his female readership socially unrecognisable 
Orpheus actually excludes respectable women from their audience and this will lead to their punishment. Orpheus is torn apart by the married women of Thrace, ${ }^{44}$ a hidden audience, and Ovid is banished because his Art of Love taught adultery. In the end, Orpheus and Ovid are punished for undermining marriage.

The passage from the Art of Love clearly refers to Augustus' lex Iulia de adulteriis coercendis, which criminalised adultery and polarised women into two social categories (matrons and prostitutes) by identifying each group with a distinguishing dress. Ovid's disclaimer resembles a testimony given in court in support of his 'Art of Courtship'. In a later reiteration of the programmatic disclaimer (en iterum testor: nihil hic nisi lege remissum/ luditur; in nostris instita nulla iocis. 'Look, I testify again: nothing unless it is granted by law is in play here; there is no long hem in our games' $)^{45}$ it becomes clear that Ovid imagines himself testifying in court about the legitimacy of his love poetry. But poetic imagination soon turned into historical reality; the exiled poet repeats almost verbatim his first disclaimer in his letter to Augustus, ${ }^{46}$ arguing that his Art of Love did not break imperial legislation.

\section{MYrRha AND THE LAW}

Courtroom rhetoric features prominently in the story of Myrrha, a nod to the reader that Orpheus' narrative needs to be read vis-à-vis Roman law. Cupid, says Orpheus, argues that he had nothing to do with Myrrha's incestuous passion and defends himself against accusations concerning his alleged involvement in the crime. Cupid's language is evocative of language used in court:

Ipse negat nocuisse tibi sua tela Cupido,

Myrrha, facesque suas a crimine vindicat isto;

stipite te Stygio tumidisque adflavit echidnis

e tribus una soror. scelus est odisse parentem,

hic amor est odio maius scelus.

Cupid himself avers that his missiles did not harm you, Myrrha, and absolves his torches from this crime of yours. One of the three sisters breathed on you with a Stygian firebrand and swollen vipers. It is a crime to hate your parent; this love was a crime greater than hatred. ${ }^{47}$

rather than excluding respectable women from his audience. Such a daring move clashes with Augustan legislation, which enforced specific dress codes as a means of identifying and displaying the moral and social status of women.

44 Nurus Ciconum, Metamorphoses 11.3; nurus means 'young married women' (Oxford Latin Dictionary 2). Reed, above n 34, 395, argues that it refers to 'young marriageable women' who are offended by Orpheus' lack of interest in marriage. In Vergil's Georgics 4.520, matres ('mothers') tear Orpheus apart. For text and translation of the Georgics, see Virgil, Eclogues. Georgics. Aeneid: Books 1-6 (H Rushton Fairclough trans, revised by GP Goold, Loeb Classical Library 1916).

45 Art of Love 2.599-2.600.

46 Tristia 2.247-50. For text and translation of Tristia 2, see Jennifer Ingleheart, $A$ Commentary on Ovid, Tristia, Book 2 (Oxford University Press, 2010).

47 Metamorphoses 10.311-10.315. Translated from Tarrant, above n 11. 
Orpheus puts his audience and Ovid puts his readers in the place of judges listening to Cupid's testimony in a legal dispute. ${ }^{48}$ As judges in this lawsuit, we should not forget that Cupid is the archetypal deceiver. In this case, Cupid has the onus of mythological tradition against him. In other versions, Venus punishes Myrrha ${ }^{49}$ because her mother boasted that her daughter was more beautiful than the goddess. ${ }^{50}$ Cupid's argument is also undermined by the structure and themes of Orpheus' narrative, in which Venus plays a key role in punishing the Cerastae and the Propoetides, who denied her divinity, and helping Pygmalion. More to the point, right after the story of Myrrha, Orpheus says that Venus fell in love with Adonis, Myrrha's son, who thus avenged his mother's passion (iam placet et Veneri matrisque ulciscitur ignes. 'Now Adonis pleases even Venus and avenges his mother's flames of passion'51). Suddenly, Cupid's mother is responsible for Myrrha's love. Orpheus himself belies Cupid's claim reminding us that the mischievous god is not only an expert in law but also a master of legal and amatory deception. ${ }^{52}$

The transition from the story of Pygmalion to the tale of Myrrha already resonates with the debate about Augustus' marriage legislation. Cinyras, Myrrha's father, is the son of Paphos, the daughter of Pygmalion:

Editus hac ille est, qui si sine prole fuisset, inter felices Cinyras potuisset haberi.

dira canam.

Born from her (i.e. Paphos) is Cinyras, the man who, had he been without offspring, he could have been counted among the fortunate. I shall sing a dreadful song. ${ }^{53}$

Given the tragedy of Cinyras due to his daughter's love for him, the opening statement is fully justified and evokes the genre of tragedy. ${ }^{54} \mathrm{It}$ would have been much better had Cinyras not been a father. The meaning of felix (not only 'fortunate' but also 'fertile') emphasises the paradox of the claim. While a man is considered felix when he has children, Cinyras is doomed precisely because he fathered a daughter. The word order (felices Cinyras) suggests e contrario the etymology of Cinyras from kinuromai

48 On the interaction between literary and legal judgement in Ovid, see Balsley, above $n 8$.

49 For other mythological versions, see Reed, above n 34, 311-314.

50 See Hyginus, Fabula 58.1 with Reed, above n 34, 311-314. For text and translation of Hyginus, see Apollodorus' Library and Hyginus' Fabulae: Two Handbooks of Greek Mythology (R Scott Smith and Stephen M Trzaskoma trans, Hackett Classics, 2007).

51 Metamorphoses 10.524. For the Latin text, see Tarrant, above n 11.

52 Cupid appears as an expert in law (a iurisconsultus) at Heroides 20.29-20.30. In this love letter, Cupid's legal advice is closely related to amatory deception. See EJ Kenney, Ovid: Heroides XVI-XXI (Cambridge University Press, 1996).

53 Metamorphoses 10.299-10.301. Translated from Tarrant, above n 11.

54 See Orestes' wish that he would rather die childless (Aeschylus, Libation Bearers 1006). For text and translation, see Aeschylus, Oresteia: Agamemnon. LibationBearers. Eumenides (Alan H Sommerstein edition and trans, Loeb Classical Library, 2009). 
('I lament', 'bewail'), anticipating the tragic fate of the king. ${ }^{55}$ Orpheus' daringly revisionist statement that a man would have been happy had he not had children befits a bard who recently renounced women and thus gave up any hope for begetting children. We can trace the voice of the homosexual Orpheus in the introduction of Cinyras. ${ }^{56}$

For Ovid's contemporary readers, Orpheus' opening statement raises a particularly sensitive issue. Augustus' marriage legislation rewarded married fathers and penalised the childless and unmarried. According to Dio Cassius, ${ }^{57}$ when the knights, the social class to which Ovid belonged, were seeking the repeal of the law regarding the unmarried and the childless, Augustus assembled the Roman citizens into two groups: the married and the unmarried. Upon seeing that the latter far outnumbered the former, he gave two speeches. He praised the married men and harangued the childless. The emperor elaborates on the blessing of having children and warns the unmarried as follows: 'you introduce customs/laws (nomous) and practices which, if imitated, would lead to the extermination of all mankind, and, if abhorred, would end in your own punishment'. ${ }^{58}$ The emperor's speech admonishes those who refuse to marry and have children, implying that those who introduce laws and customs that go against imperial legislation will be punished.

Orpheus' institution of novel regulations that undermine marriage leads to his punishment within the narrative of the Metamorphoses. Outside the narrative, Orpheus' statement is a rebuttal of the emperor's praise for begetting children. Augustus admitted that 'there are disagreeable and painful things incident to marriage and the begetting of children' and added that 'we do not possess any other good with which some unpleasantness is not mingled, and that in our most abundant and greatest blessings there reside the most abundant and greatest evils' ${ }^{59}$ The tale of Cinyras highlights that begetting children might be not just a mixed blessing, but pure disaster. As the voice of the bard converges with the voice of those who objected to Augustus' marriage laws, the tale of Myrrha is introduced as a myth illustrating the misfortunes of having children. In other words, Myrrha is an excellent myth if the aim is birth control, but Augustus' demographic concerns were exactly the opposite and he needed myths with a different moral.

55 Cf Reed, above n 34, 233. Kinura is a string instrument played with a plectrum. Its etymological association with Cinyras' lamentable fate is relevant to Orpheus' recital. We can imagine the bard playing his lyre in the plaintive tune of the kinura, while he is singing of Cinyras' tragic tale. Ovid refers to Orpheus' lyre and his key changes in Metamorphoses 10.148-10.154.

56 On the relevance of Orpheus' new sexual orientation to his recital, see John F Makowski, 'Bisexual Orpheus: Pederasty and Parody in Ovid' (1996) 92 Classical Journal 25; Matthew Fox, 'The Bisexuality of Orpheus' in Mark Masterson, Nancy Sorkin Rabinowitz and James Robson (eds), Sex in Antiquity: Exploring Gender and Sexuality in the Ancient World (Routledge, 2015) 335-351.

57 Roman History 56.1-56.10. For text and translation, see Dio Cassius, Roman History (Earnest Cary trans, Loeb Classical Library, 1924) vol 7.

58 Roman History 56.4.

59 Roman History 56.8. 
We can actually push this line of argument further, if we consider that Augustus, like Cinyras, had an only daughter who made her father unhappy. The shameless behaviour of the adulterous Julia deeply distressed the emperor, who finally exiled her, a punishment that is reminiscent of the wandering Myrrha ${ }^{60}$ Despite his burning desire for a successor, Augustus, not unlike Cinyras, would have been more fortunate had he been childless. Suetonius attests that Augustus would sigh every time he would hear the name Julia, referring either to his daughter or his equally adulterous granddaughter:

[A]nd at every mention of him (i.e. Agrippa) and of the Julias he would sigh deeply and even cry out:

'Would that I never had wedded and would I had died without offspring'; and he never alluded to them except as his three boils and his three ulcers. ${ }^{61}$

Orpheus' introduction of Cinyras clearly echoes the words of Augustus, merging together Greek myth and Roman reality.

Ovid's Orpheus takes part in current debates on Augustan legislation but also raises fundamental issues about the origins of justice. The tale of Myrrha revolves around a controversial argument of whether the laws of nature are superior to human legislation. ${ }^{62}$ For Myrrha, desire and sexual attraction precede and thus surpass the arbitrary laws of human societies that forbid incestuous affairs. ${ }^{63}$ The heroine contrasts the laws of the first Venus with human law. The absolute power of physical attraction is pitted against the relative value of social norms. The controversy is skilfully summarised in Orpheus' ambiguous line si tamen admissum sinit hoc natura videri. ${ }^{64}$ Depending on whether we take admissum as a noun ('crime', 'wrong') or a participle ('permitted'), we are faced with two contrasting translations: "but if nature allows this crime to come to light' or 'but if nature allows this deed to seem permissible'. ${ }^{65}$ Is nature committing a crime or is she legitimising incest?

Myrrha is obsessed with this question. Orpheus gives us the girl's soliloquy, ${ }^{66}$ a dramatic monologue that draws on the tradition of heroines who are torn between their personal passions and family duties (Euripides' Phaedra or Medea, for instance). Myrrha's soliloquy is also a suasoria or

$60 \quad$ Metamorphoses 10.478-10.481.

61 Suetonius, Augustus 65.4. Translation from Suetonius, The Lives of the Caesars: Julius. Augustus. Tiberius. Gaius. Caligula, Volume 1 (JC Rolfe trans, Loeb Classical Library, 1914). Augustus quotes Homer, Iliad 3.40. For the text of the Iliad, see Martin L West, Homeri Ilias (Teubner 1998-2000). For a translation, see Richmond Lattimore, The Iliad of Homer (University of Chicago Press, 2011).

62 See, Gebhardt, above n 24, 321-334.

63 On Roman law and incest, see Philippe Moreau, Incestus et Prohibitae Nuptiae: Conception romaine de l'inceste et histoire des prohibitions matrimoniales pour cause de parenté dans la Rome antique (Les Belles Lettres, 2002).

64 Metamorphoses 10.304. Translated from Tarrant, above n 11.

65 See Reed, above n 34, 234.

66 Metamorphoses. 10.320-10.355. 
controversia, a classroom exercise on a mythical or imaginary legal dispute that aimed at preparing Roman schoolboys for a career in the forum. ${ }^{67}$

Myrrha begins her speech by praying to the gods and to the sacred ancestral laws to forbid her unholy passion and stop the unspeakable crime. ${ }^{68}$ But once she utters the word scelus ('crime'), she starts wondering whether her love for her father is indeed a crime. With the legal rhetoric and arguments of her suasoria, ${ }^{69}$ she attempts to justify her desire on the basis that piety does not separate sexual attraction from filial affection:

Sed enim damnare negatur

hanc Venerem pietas: coeunt animalia nullo cetera delicto

But they say that piety refuses to condemn this Venus: other animals mate without offense. ${ }^{70}$

Again, we note the procedural use of negatur and the legal terms damnare and delicto. To buttress her argument, she gives the example of animals and birds, which do not shy away from fathering children with their offspring. For the heroine, human laws against incest are merely a product of human spite and envy against nature. In fact, besides the world of birds and animals, several human societies, Myrrha avers, allow incest.

The genre and effects of Myrrha's speech change depending on the different audiences that are woven into Ovid's narrative. ${ }^{71}$ The heroine's soliloquy exposes her isolation and troubled mind since within the story Myrrha has no audience. But her arguments about the superior laws of natural attraction resonate with Orpheus' audience of animals and birds. On another level, two hidden audiences lurk behind Orpheus' recital. One consists of the Thracian matrons and the other of Ovid's readers. For Ovid's Roman readership, Myrrha resembles a student who performs a rhetorical suasoria. In fact, her speech includes both sides of the controversy, arguments justifying and condemning her incestuous passion. The simultaneous inclusion of conflicting arguments combines the performance of classroom exercises with the dramatic effect of the vacillating heroine.

67 Ovid thoroughly enjoyed inserting suasoriae in his poetry and has often been criticised for it by older scholars who perceived rhetoric as undermining poetry. Orpheus' speech to Pluto and Persephone is another example of suasoria; see Russ VerSteeg and Nina Barclay, 'Rhetoric and Law in Ovid's Orpheus' (2003) 15(3) Law and Literature 395. For rhetoric in Ovid, see Ulrike Auhagen, 'Rhetoric and Ovid' in William Dominik and Jon Hall (eds), A Companion to Roman Rhetoric (Blackwell Publishing, 2007).

68 Metamorphoses 10.321-10.322.

69 Metamorphoses 10.323-10.335.

70 Metamorphoses 10.323-10.325. Translated from Tarrant, above n 11.

71 On the importance of the audience, internal and external, in the Metamorphoses, see Stephen M Wheeler, A Discourse of Wonders: Audience and Performance in Ovid's Metamorphoses (University of Pennsylvania Press, 1999). 
While the suasoriae were neither about real courtroom cases nor about real people, Myrrha's suasoria is a mythological reality. The heroine deals with the real and personal problem of her burning desire, not with routine homework, which involved lurid scenarios as a means of motivating students. ${ }^{72}$ Her masterful arguments on a legally disputed case exemplify the profile of Amor as a teacher of love, law, and rhetoric. It is the confluence of ars oratoria and ars amatoria that ultimately dictates the rules of lex amatoria. ${ }^{73}$ Myrrha's sexual desire for her father turns her into a summa cum laude student of legal theory and practice.

Myrrha attempts a radical redefinition of pietas ('family duty') by combining, or confusing, duty with love and filial affection with physical attraction. Part of the striking effect of her suasoria is related to her gender. Myrrha excels in a legal exercise regularly assigned to Roman schoolboys with aspirations for a career in law. ${ }^{74}$ Paradoxically, the heroine launches an attack on the legal principles of patriarchy as a result of her passionate love for her father. Her provocatively revisionist laws of love would seriously undermine the legal power of the Roman father, the so-called patria potestas. In Roman law, a young woman would pass from the potestas of the father to the potestas of the husband. ${ }^{75}$ Of course, Myrrha's incestuous love is open to Freudian interpretations, but Ovid may be actually picking on something more specific, namely on the fact that from a legal perspective the relationship between a daughter and a father was similar to that of a wife and husband. ${ }^{76}$ The heroine falls in love with her father, a comment on the legally equivalent positions of daughters and wives. What is more, a young Roman woman often faced the prospect of marrying a husband of an age similar to her father's. This is suggested when Orpheus speculates that Myrrha and Cinyras called each other 'father' and 'daughter' in bed. ${ }^{77}$ Within Orpheus' narrative, the

72 Incest and sexual transgressions were common topics of controuersiae.

73 Goodrich, above n 2, 10, 21, 51, 177, employs the portmanteau neologism ars rectorica, in order to highlight the confluence of the rules of love (rectus) and the art of rhetoric (ars oratoria).

74 On the close association of rhetorical education with masculinity, see Joy Connolly, 'Virile Tongues: Rhetoric and Masculinity' in William Dominik and Jon Hall (eds), A Companion to Roman Rhetoric (Blackwell Publishing, 2007).

75 A woman would be under the potestas of her husband in the case of a marriage cum manu. For the legal aspect of the manus marriage, see Treggiari, above $\mathrm{n} 14$, 27-32; Karen H Hersch, The Roman Wedding: Ritual and Meaning in Antinquity (Cambridge University Press, 2010) 23-27.

76 See Gaius, Institutes 1.108 (WM Gordon and OF Robinson trans, Duckworth, 1988). Alan Watson, Roman Law and Comparative Law (University of Georgia Press, 1991) 27 notes: 'The older, marriage cum manu, put the wife under the power of her husband ...; she was said to be in the legal position of a daughter, and any property she owned became his'. Ovid refers to this older form of marriage, in order to stress that according to Roman law's legal fictions a daughter is indistinguishable from a wife.

77 Metamorphoses 10.467-10.468. Michèle Lowrie, 'Myrrha's Second Taboo: Metamorphoses 10.467-68' (1993) 88(1) Classical Philology 50 sees a transgression of a religious taboo here. 
story of Myrrha is a tale of heterosexual pederasty, of a young girl who falls in love not just with a father figure but with her own father. But for Ovid's audience, the myth nods to the accepted age difference in Roman marriage. From that perspective, Roman laws and customs can be held responsible for Myrrha's category confusion.

It is likely that Augustus' marriage legislation limited the absolute power of the father. A young woman had to consent to her marriage and her father could not force her to marry against her will. ${ }^{78}$ Instead of choosing a husband for her daughter, Cinyras is at a loss in the face of numerous suitors and asks his daughter to choose who she wants to marry. ${ }^{79}$ When Myrrha responds that she wants a husband like her father, Cinyras is happy since he misconstrues her response as pietas ('family duty'). It is Myrrha's freedom of choice that ultimately undermines Cinyras' paternal power. Once the absolute power of a father to marry his daughter at a very young age to whomever he wished is compromised, the furies of uncontrollable female sexuality wreak havoc on family ties. Even though the overall portrayal of Myrrha is sympathetic, Orpheus' tale is open to conservative patriarchal interpretations and can be construed as misogynistic. ${ }^{80}$ This is indicative of the openness of Ovid's poetry to different interpretations as well as literary and moral judgments. The readers are implicitly invited to pass judgment on Myrrha, a decision that becomes all the more difficult and controversial since the story can be subjected to both feminist and misogynistic readings.

The heroine's desire to possess her father brings up a tension between female passion and male legislation. The patria potestas competes with the daughter's resolution to dominate her father and the rules and motifs of Latin love poetry challenge ancestral laws. Myrrha's decision to die if she does not conquer her father (si non potiatur amore, ${ }^{81}$ 'if she does not possess her passion') transforms the juxtaposition between love and death, which is a main preoccupation of Latin love poetry, into a choice between death and female potestas in family and sex. Myrrha's nurse echoes the heroine's desire and diction (potiere tuo ... parente, ${ }^{82}$ 'possess your ... father'), implying that Myrrha's incestuous love is a desire to appropriate the patria potestas. ${ }^{83}$ The young woman wants both the body and the power of her father.

The consummation of Myrrha's passion is presented as a perverse wedding ceremony ${ }^{84}$ led by the awfully diligent nurse, an old woman who

78 See Anne Videau, 'L'écriture juridique d'Ovide des élégies amoureuses (Amours et Héroïdes) aux Tristes de l'exil' (2004) 2 Ars Scribendi.

79 Metamorphoses 10.356-10.366.

80 Makowski, above n 56; Rachel Bruzzone, 'Statues, Celibates and Goddesses in Ovid's Metamorphoses 10 and Euripides' Hippolytus' (2012) 108(1) Classical Journal 65 interpret Orpheus' stories as misogynistic.

81 Metamorphoses 10.428. Translated from Tarrant, above n 11.

82 Metamorphoses 10.429. Translated from Tarrant, above $\mathrm{n} 11$.

83 Potestas ('power') is etymologically related to potior ('I have power', 'I possess').

84 See Shawn O'Bryhim, 'Myrrha's Wedding (Ov Met 10.446-10.470)' (2008) 58(1)

Classical Quarterly 190. 
has telling similarities with an old bawd ${ }^{85}$ and a pronuba, the woman who conducts the bride to the bridal chamber. Cinyras lies in darkness not realising that he is about to sleep with his daughter. Myrrha's identity is covered by a starless night, a dark shroud that perversely functions as the veil of the Roman bride. Myrrha holds her nurse's hand (nutricisque manum ... tenet) and, while groping over her way in darkness, she is led (ducitur) in Cinyras' bedroom, pointedly described as thalamus 'bridal chamber' ${ }^{86}$ The crossing of the chamber's threshold (limen), ${ }^{87}$ the leading of the bride (ducitur) and the handing over of the bride to the groom allude to the Roman wedding and the institution of marriage cum manu. ${ }^{88}$ From a legally perverse point of view, Myrrha symbolically marries and remains in the potestas of her father who is her husband.

Diction alluding to wedding customs and marriage laws provocatively covers Myrrha's extra-marital incest and defiant deception of her father with a bridal veil. Daring diction aside, Myrrha and Cinyras commit adultery, ${ }^{89}$ a crime punished under Augustus' lex Iulia de adulteriis coercendis. As Cinyras discovers the identity of his paramour by shedding light on his bedroom, Roman law heightens the irony of this crucial moment. Cinyras' first reaction is to draw his sword from his sheath and attempt to kill Myrrha. A father who would catch his daughter committing adultery in his household had the right to kill her, provided he caught her in the act and killed her on the spot. But he had to kill both the daughter and the adulterer, either both or neither of them. ${ }^{90}$ Cinyras' decision to kill his daughter is bitterly ironic since it implies that next he had to kill himself as a father killing an adulterer. ${ }^{91}$ The narrative abandons the king and follows Myrrha, the main heroine of the myth, as she flees from Cyprus and wanders in the Middle East. ${ }^{92}$ Myrrha's love has upset patriarchal legislation by ruining her father, the man who gave her life and whom she loved more than her life.

85 Like the decrepit bawds of comedy and elegy, the nurse advertises the charms of the girl she is offering to a drunken Cinyras (Metamorphoses 10.437-10.443).

86 Metamorphoses 10.455-10.457.

87 Metamorphoses 10.456; cf Catullus 66.17. Translated from Tarrant, above n 11. For text and translation of Catullus, see Peter Green, The Poems of Catullus (University of California Press, 2007).

88 Cf manu deducit, Metamorphoses 10.462. When Myrrha hesitates, the nurse pushes her and the language of wedding customs becomes highly ironic; cf Franz Bömer, P Ovidius Naso Metamorphosen Buch X-XI (Carl Winter, 1980) 157.

89 A marriageable girl (virgo) who had an extra-marital affair and a man who had an affair with a virgo were committing stuprum ('criminal fornication'), but the lex Iulia conflates stuprum with adulterium; see McGinn, above n 14, 144-152.

90 For the father's ius occidendi ('right to kill') and Augustus' lex Iulia, see McGinn, above n 14, 202-207.

91 Ovid does not tell us what happened to Cinyras after Myrrha escaped, but in some versions of the myth he commits suicide after realising that he had sex with his daughter; see Hyginus, Fabulae 242. For text and translation of Hyginus, see Smith and Trzaskoma, above n 50.

92 Myrrha's subsequent exile alludes to the punishment for adultery; see McGinn, above n 14, 143, 166. 


\section{Conclusion}

Orpheus is a mythic figure often associated with the power of his song and his devotion to his dead wife. Less known are the aspects of the myth that link Orpheus to the institution of pederasty and present him as one of the first legislators. These different facets of the myth are interconnected. Poetry, desire, and the law depend on each other to the extent that dictate and prescribe each other. The bard has the power to change the world with his harmonious song and civilise human intercourse. Desire is subjected to the civilising force of poetry, which can tame and bend the laws of nature.

The illocutionary power of Orpheus' song makes his poetry a speech act in competition with legal discourse. Ovid's Orpheus exemplifies a tension between the legislative power of poetry and the mandates of imperial statutes. As a figure establishing the laws that regulate desire, Orpheus competes with secular marriage legislation. The bard is a figure of Ovid, who spelled out the constitution of the rules of conduct within the domains of sexual attraction in his Art of Love and was punished for subverting the institution of marriage. Given the similarities between Ovid and Orpheus, the tale of Myrrha should be read against the background of Augustus' legal reforms concerning marriage and adultery. While the historical reading of Ovid's tale shows that his Myrrha provocatively subverts the institution of Roman marriage and also warns about the perils of having children in sharp contrast with Augustan policies, the transhistorical value of the myth reveals a fundamental antagonism between the dominance of subjective desire and the power of objective regulations. The laws of the first Venus override secular legislation and Orpheus, one of the first lawmakers, knows well that law and love both complement and antagonise each other. 